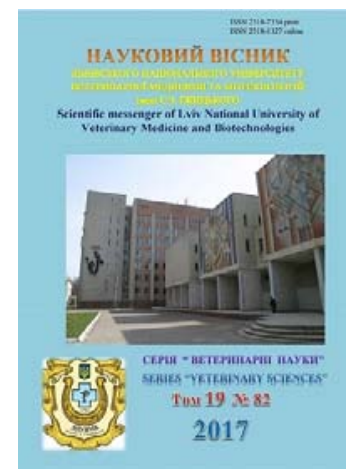

Науковий вісник Львівського національного університету ветеринарної медицини та біотехнологій імені С.З. Гжицького

Scientific Messenger of Lviv National University of Veterinary Medicine and Biotechnologies

doi:10.15421/nvlvet8220

ISSN 2518-7554 print

ISSN 2518-1327 online

$\underline{\text { http://nvlvet.com.ua/ }}$

УДК 63.577.534

\title{
Характеристика сучасних методів визначення сирого протеїну у кормах та рослинній сировині
}

\author{
Г.В. Кушнір, Т.Р. Левицький, Г.П. Ривак, Л.В. Курилас, О.М. Вільха, Г.Ю. Федор \\ galmwi@ukr.net
}

Державний науково-дослідний контрольний інститут ветеринарних препаратів та кормових добавок, вул. Донецькка, 11, м. Львів, 79019, Україна

\begin{abstract}
Сьогодні у лабораторній і виробничій практиці ветеринарної медицини України для визначення сирого протеїну в кормах та рослинній сировині використовують як класичні, так і сучасні методи, залежно від мети та завдань досліджень. Тому, в статті охарактеризовано сучасні методи визначення вмісту азоту і обчислення сирого білка в кормах для тварин і рослинній сировині, зокрема, фотометричному, класичному - методу К'сльдаля, сучасних - Дюма та спектрометричному (метод інфрачервоної спектрометрії в ближньому діапазоні (БІЧ-спектрометрії). Незважаючи на те, що метод К'єльдаля залишається загальновизнаним при визначенні білка і його найчастіше використовують при дослідженнях, проте сучасні методи - метод Дюма і БІЧ-спектрометрії, набувають широкого впровадження у лабораторній практиці. Основною перевагою цих методів є швидкість проведення аналізу (на одне визначення потрібно лише декілька хвилин), практично відсутня пробопідготовка, і щзо найголовныше не використовуються токсичні хімічні речовин $i$ каталізатори.
\end{abstract}

Ключові слова: корми, рослинна сировина, азот, сирий протеїн, метод К'єльдаля, метод Дюма, спектрометричний метод.

\section{Характеристика современных методов определения сырого протеина в кормах и растительном сырье}

\author{
Г.В. Кушнир, Т.Р. Левицкий, Г.П. Рывак, Л.В. Курылас, О.М. Вильха, Г.Ю. Федор \\ galmwi@ukr.net
}

Государственный научно-исследовательский контрольный институт ветеринарных препаратов и кормовых добавок, ул. Донеикая, 11, г. Львов, 79019, Украина

\begin{abstract}
Сегодня в лабораторной и производственной практике ветеринарной медицины Украины для определения сырого протеина в кормах и растительном сырье используют как классические, так и современные методы в зависимости от иели и задач исследований. Поэтому в статье охарактеризованы современные методы определения содержания азота и вычисление сырого белка в кормах для животных и растительном сырье, в частности, фотометрическом, классическом - методом Кьельдаля, современных - Дюма и спектрометрическом (инфракрасной спектрометрии в ближнем диапазоне (БИК-спектрометрии). Несмотря на то, что метод Кьельдаля остается общепризнанным при определении белка и его чаще всего используют при исследованиях, однако современные методы - метод Дюма и БИКспектрометрии, получают широкое внедрение в лабораторной практике. Основным преимуществом этих методов является скорость проведения анализа (на одно определение нужно лишь несколько минут), практически отсутствует пробоподготовка, и самое главное не используются токсичные химические веществ и катализаторы.

Ключевые слова: корма, растительное сырье, азот, сырой протеин, метод Кьельдаля, метод Дюма, спектрометрический метод.
\end{abstract}

\section{Citation:}

Kuchnir, G.V., Levytzkiy, T.R., Ryvak, G.P., Kurylas, L.V., Vilha, O.M., Fedor, G.Y. (2017). The characteristics of modern methods for the determination of raw protein in feeds and in plant materials. Scientific Messenger LNUVMB, 19(82), 97-100. 


\title{
The characteristics of modern methods for the determination of raw protein in feeds and in plant materials
}

\author{
G.V. Kuchnir, T.R. Levytzkiy, G.P. Ryvak, L.V. Kurylas, O.M. Vilha, G.Y. Fedor \\ galmwi@ukr.net
}

\author{
State Scientific-Research Control Institute of Veterenary Medicinal Products and Feed Additives \\ Donetska Str., 11, Lviv, 79019, Ukraine
}

\begin{abstract}
Todays in laboratory and manufacturing practice of veterinary medicine of Ukraine, for the detertimations of raw protein in feed and in plant raw are used as classic and as modern methods depending from the aim and the task of research. Thats why the article describes the modern methods of the determination of content of nitrogen and the calculation of raw protein in feeds for animals and in plant materials, in particular, photometric, classical - Kjeldahl method, modern - Dumas and spectrometric methods (the method of infrared spectrometry in the near range (NIR-spectrometry). Despite of the facts, that the Kjeldahl method remains generally accepted in the determination of the protein and is most often used in research, but the modern methods - the Dumas method and NIR-spectrometry are widely adopted in laboratory practice. The main advantage of these methods is the speed of the analysis (the one definition takes only a few minutes), practically there is no sample preparation, and the most important is that the toxic chemicals and catalysts are not used.

Thus, despite the fact that the Kjeldahl method remains generally accepted in the determination of the protein, and it is most frequently used in research, but modern methods, the Dumas method and NIR-spectrometry, are widely implemented in laboratory practice. The main advantage of these methods is the speed of conducting the analysis (one definition only takes a few minutes), there is practically no sample preparation, and most importantly, toxic chemicals and catalysts are not used.
\end{abstract}

Keywords: feed, plant raw, nitrogen, raw protein, Kjeldahl method, Dumas method, spectrometric method.

\section{Вступ}

Із усіх поживних речовин, які відіграють важливу роль у забезпеченні життєдіяльності живого організму, провідне місце відводиться білкам (протеїнам), оскільки вони є основою всіх життєвих функцій організму тварин. Протеїни - це органічні сполуки, до складу яких входить азот. У рослинних кормах азотисті речовини називають «сирим протеїном», який складається із двох груп речовин - білка та амідів. Всі білки незалежно від структури, властивостей і функцій, побудовані з одних і тих самих амінокислот, проте вони відрізняються один від одного кількісним співвідношенням. Білки мають особливо важливе значення для живлення і життя сільськогосподарських тварин і птиці. Вони є структурним матеріалом організму і носієм життя, оскільки всі життєві процеси пов'язані з білковим обміном. Аміди - це азотисті речовини небілкового походження, які містять вільні амінокислоти, аміди амінокислот і глюкозиди. Крім того, слід відзначити, що аміди використовуються тваринами, особливо жуйними, для синтезу білка (Ibatullin et al., 2015). Білки в організмі тварин використовуються як структурні речовини для побудови клітин, синтезу ферментів, гормонів, імунних тіл, а під час дезамінування та окиснення - як джерело енергії. Вони надходять до організму сільськогосподарських тварин через згодовування різноманітних кормів, які відрізняються за складом і поживністю. Вміст протеїну в кормі залежить від його виду, способу заготівлі, зберігання та технології приготування корму. Рівень протеїну в кормах коливається в широких межах - від 0,5 до 80\%. Багаті на протеїн - зерно бобових (20-30\%), макуха і шрот (30-40\%), дріжджі (45-50\%) та корми тваринного походження (40-80\%). Серед кормів тваринного походження найбільше протеїну в кров'яному (80\%), пір'яному (70\%), м'ясному i рибному (50-65\%), м'ясо-кістковому (30-40\%) бо- рошні та сухому збираному молоці (40\%). Мало білка в коренебульбоплодах $(0,5-1,5 \%)$, соломі (3-6\%), залишках цукробурякового виробництва - жомі $(1,2 \%)$, мелясі $(8,5 \%)$, злакові рослини містять середню кількість протеїну - 10-15\% (Busenko et al., 2015).

Підвищення ефективності використання наявних кормів є головним завданням у годівлі тварин. Саме тому важливим $є$ кількісне визначення протеїну корму, який розраховують за кількістю азоту, що наявний в кормі. Дослідженнями встановлено, що білок тваринних тканин містить $16,0 \%$ азоту, зернових $17,5 \%$, кукурудзи - 16,7\% тощо. Для різних біологічних об'єктів розраховані індивідуальні коефіцієнти перерахунку масової частки азоту в білок. Зокрема, для пшениці і рису він становить - 5,83, ячменю, вівса і жита $-5,70$, кукурудзи - 5,95, молочної сироватки 6,38 , сої - 5,41, білки тваринних тканин та висівок 6,25 (Kostenko et al., 2008).

Показник «сирий протеїн» означає кількість загального азоту, який визначено у зразку одним із аналітичних методів, помножений на відповідний коефіцієнт. При виробництві комбікормів чи білкововітамінно-мінеральних добавок для перерахунку загального азоту в протеїн виробники завжди використовують коефіцієнт 6,25. У середньому прийнято, що вміст азоту в протеїні становить $16 \%$. Звідси коефіці$\epsilon$ пт переведення азоту в протеїн 6,25 (100:16), при цьому індивідуальні коефіцієнти для різного виду сировини не враховують, щоб не було плутанини між постачальниками сировини, виробниками і споживачами комбікормів (Ibatullin et al., 2015).

Сьогоднішні для визначення загального азоту 3 подальшим перерахунком в сирий протеїн використовують різні методи, зокрема, фотометричний, класичний - метод К'єльдаля, сучасні - метод Дюма та спектрометричний (інфрачервоної спектрометрії в ближньому діапазоні (БІЧ-спектрометріiі) (DSTU ISO 5983:2003; Bekker, 2009; GOST R 54390-2011). 
Фотометричний метод внесений до державного стандарту для визначення загального азоту/сирого протеїну. В основі методу лежить розкладання органічних речовин дослідного зразку концентрованою сірчаною кислотою з утворенням солей амонію і подальшим фотометричним визначенням азоту у вигляді забарвленої індофенольної сполуки, що утворюється в лужному середовищі при взаємодії 3 саліцилатом i гіпохлоритом натрію і має максимум світло поглинання за довжиною хвилі 655 нм. Концентрація азоту в фотометричних розчинах повинна знаходитися в

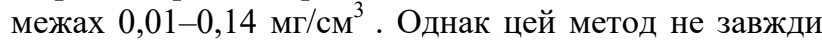
підходить для багатокомпонентних зразків.

Метод К'єльдаля надалі залишається загальновизнаним методом визначення білка і найчастіше використовується в якості еталонного для калібрування інших методів визначення масової частки білка і приладів для експрес-аналізу. Цей метод внесений до державних стандартів як арбітражний і широко використовується як в лабораторіях, так і на комбікормових підприємствах (DSTU ISO 5983:2003).

Визначення загального азоту за методом К'єльдаля проходить у три етапи: мінералізація (розкладання) зразка, нейтралізація кислоти концентрованим лугом 3 наступною перегонкою (дистиляцією) водяною парою, титруванням перегнаного дистиляту розчином кислоти або лугу відомої концентрації (титрантом).

Мінералізацію (розкладання) зразка проводять за температури 44-440 ${ }^{\circ} \mathrm{C}$ при наявності концентрованої сірчаної кислоти і каталізатора. Азот $(\mathrm{N})$ із зразка у вигляді аміаку, зв'язується 3 сірчаною кислотою 3 утворенням сульфату амонію $\left(\mathrm{NH}_{4}\right)_{2} \mathrm{SO}_{4}$. Мінералізат охолоджують, а потім розбавляють водою і нейтралізують концентрованим натрієвим лугом, в результаті чого утворюється гідроокис амонію:

$\mathrm{NH}_{4} \mathrm{OH}\left(\left(\mathrm{NH}_{4}\right)_{2} \mathrm{SO}_{4}+2 \mathrm{NaOH}=2 \mathrm{NH}_{4} \mathrm{OH}+\mathrm{Na}_{2} \mathrm{SO}_{3}\right.$

Це нестійка сполука, яка розкладається на аміак i воду при нагріванні водяною парою.

Наступний етап - перегонка (дистиляція) водяною парою. При цьому аміак разом 3 парою попадає в прийомну колбу, де аміак зв'язується із розчином борної кислоти. Потім дистилят титрують розчином сірчаної кислоти. За кількістю реагенту, який був витрачений на титрування зв'язаного аміаку, визначають вміст загального білка.

Метод К'єльдаля застосовують в ручному, напівавтоматичному і автоматичному режимах. При цьому принцип методу залишається тим самим, тільки при автоматизації процесу в 2-3 рази зростає продуктивність праці оператора і при цьому знижується вплив людського фактора на кінцевий результат. Крім того, зменшується кількість шкідливих викидів у навколишнє середовище і знижуються енерговитрати.

Широкого впровадження у лабораторній практиці набув метод Дюма. Його часто використовують в Свропі, Америці, Росії при експортних операціях для швидкого визначення концентрації білка. При визначенні азоту цим методом зразок спалюється за високої температури $\left(900-1030^{\circ} \mathrm{C}\right)$ у спеціальній лунці в атмосфері кисню при наявності каталізаторів, внаслідок чого вивільняється $\mathrm{CO}_{2}, \mathrm{H}_{2} \mathrm{O}$ и $\mathrm{N}_{2}$. Вуглекислий газ $\mathrm{i}$ вода видаляються шляхом пропускання через спеціа- льні колонки, які поглинають їх, а вміст азоту, що виділився визначають інноваційним самокалібрувальним детектором за теплопровідностю (TCD) LoGas ${ }^{\mathrm{TM}}$ (для його роботи не потрібний газ порівняння) і порівнюють 3 калібрувальною кривою (GOST R 543902011).

Основною перевагою цього методу є швидкість проведення аналізу. При його проведенні не використовуються токсичні хімічні речовини і каталізатори, i практично відсутня пробопідготовка (тільки розмел проби), а на одне визначення потрібно лише декілька хвилин, тоді як при використанні метода К'єльдаля затрати часу є набагато більші (1,5-2 год). Проте, недоліком цього методу є те, що невелика кількість дослідного зразку не завжди є репрезентативною, тому результати досліджень можуть бути не точними. Цей метод не $є$ арбітражним, тому при виникненні претензій між постачальником і споживачем для повторних досліджень використовують метод К'єльдаля.

За допомогою класичних аналітичних методів аналізу не завжди вдається провести належний аналіз якості сировини, та й саме проведення аналізів вимагає багато часу, реагентів, а результати залежать від кваліфікації того, хто проводить аналізи. Тому актуальним на даний момент $є$ використання сучасних інструментальних методів аналізу, які мають суттєві переваги над класичними. В нашій країні рівень автоматизації аналізу якості сільськогосподарської сировини ще досить низький. Кількість стандартизованих інструментальних методів незначна, а існуючі стандарти здебільшого приписують використання застарілих приладів.

У світовій практиці, за останні 15 років, основним напрямком розвитку аналізу стала розробка експресних інструментальних методів контролю. Серед низки інструментальних методів велику увагу привертають спектрометричні методи досліджень, що грунтуються на вибірковій взаємодії електромагнітних хвиль 3 атомно-молекулярною будовою досліджуваних речовин. У цьому відношенні провідне місце відводять методу інфрачервоної спектроскопії в ближньому діапазоні. Цей метод знайшов широке застосування в різних галузях сільського господарства (для визначення якості грунтів, вмісту білка, жиру тощо в кормах і рослинній сировині), в промисловості (для визначення складу нафтопродуктів, якості текстильних матеріалі тощо), в медицині (для визначення жиру, кисню в крові, дослідження розвитку пухлин). Сьогодні фармацевтична промисловість в Свропі та Америці широко використовує БІЧ-спектрометрію при контролі препаратів (Sadchikova et al., 2008; Scheeren et al., 2012).

Межа ближнього інфрачервоного електромагнітного випромінювання знаходиться в діапазоні довжин хвиль від 800 нм до 2500 нм (хвильових чисел від 12500 до $4000 \mathrm{~cm}^{-1}$ ), тобто вона межує з середньою інфрачервоною межею з великою довжиною хвилі і 3 видимою межею коротших хвиль. В основі методу інфрачервоної спектроскопії лежить поглинання/пропускання, відбивання або розсіювання інфрачервоного випромінювання при проходженні через дос- 
лідні зразки, та подальшим порівнянням одержаного спектру з результатами бази даних калібрувань. Електромагнітні хвилі в цьому діапазоні спектра взаємодіють 3 коливальними рухами атомів та молекул у структурі реагентів. На відміну від загальноприйнятого аналізу та ідентифікації окремих смуг поглинання у середньому діапазоні ІЧ частот, тобто спектрометричний підхід, у ближньому діапазоні використовується хемометрична методика, що полягає у встановленні кореляції між вмістом окремого компонента у суміші та інтенсивністю відповідних коливань у спектрі. Поглинання в БІЧ діапазоні пов'язано з обертонами основних коливальних частот зв'язків $\mathrm{C}-\mathrm{H}$, $\mathrm{C}=\mathrm{O}, \mathrm{N}-\mathrm{H}, \mathrm{O}-\mathrm{H}, \mathrm{S}-\mathrm{H}$ і їх комбінацій (Bekker, 2009).

Основною перевагою методу інфрачервоної спектрометрії в ближньому діапазоні $є$ можливість кореляції спектральної інформації з фізичними та хімічними властивостями і всі якісні і кількісні характеристики визначаються одночасно (одночасне кількісне визначення декількох компонентів багатокомпонентних сумішей), слабке затухання сигналу, відсутність пробопідготовки та використання розчинників, безконтактний вимір через скло, можливості вимірювання на відстані за допомогою волоконно-оптичних датчиків, час аналізу - кілька секунд. Метод БІЧ-спектрометрії для контролю якості різних об'єктів сьогодні введений до числа офіційно прийнятих у багатьох країнах.

Коротка характеристика методів визначення вмісту азоту наведена в таблиці.

Таблиия

Характеристика методів визначення вмісту азоту

\begin{tabular}{|l|c|c|c|}
\hline Значення & Метод К'єльдаля & Метод Дюма & Метод БІЧ-спектрометрії \\
\hline Дослідний зразок & $\begin{array}{c}\text { Руйнування } \\
\text { (спалювання) }\end{array}$ & $\begin{array}{c}\text { Руйнування } \\
\text { (спалювання) }\end{array}$ & Без руйнувань \\
\hline Пробопідготовка & Так & Так & Відсутня \\
\hline Час проведення аналізу & $2-4$ год. & 5 хв. (підготовка - 1 год.) & Відсутня \\
\hline Необхідність витратних матеріалів & Так & Так & Середня, або відсутня \\
\hline Підготовка спеціаліста & Висока & Висока & Ні \\
\hline Необхідність прекурсорів & Так & Ні & Лабораторія, або виробництво \\
\hline Місце проведення аналізу & Лабораторія & Ні \\
\hline Робота з високою температурою & Так $\left(440{ }^{\circ} \mathrm{C}\right)$ & Так $\left(900-1300{ }^{\circ} \mathrm{C}\right)$ & \multirow{2}{*}{ Відсутня } \\
\hline $\begin{array}{l}\text { Шкода для навколишнього сере- } \\
\text { довища }\end{array}$ & Висока & Середня & \\
\hline
\end{tabular}

Отже, незважаючи на те, що метод К'єльдаля залишається загальновизнаним при визначенні білка i його найчастіше використовують при дослідженнях, проте сучасні методи - метод Дюма i БІЧспектрометрії, набувають широкого впровадження у лабораторній практиці. Основною перевагою цих методів є швидкість проведення аналізу (на одне визначення потрібно лише декілька хвилин), практично відсутня пробопідготовка, і що саме головне не використовуються токсичні хімічні речовин і каталізатори.

\section{Висновки}

Сьогодні у лабораторній і виробничій практиці ветеринарної медицини України для визначення сирого протеїну в кормах та рослинній сировині використовують як класичні, так і сучасні методи, залежно від мети та завдань досліджень. Застосування сучасних методів Дюма та БІЧ-спектрометрії має суттєві переваги над класичними методами і тому набувають широкого застосування у лабораторній практиці.

Перспективи подальших досліджень. Провести порівняльний аналіз дослідних зразків методом К'єльдаля і методом БІЧ-спектрометрії.

\section{Бібліографічні посилання}

Ibatullin, I.I., Melnik, Yu.F., Otchenachenko, B.B. (2015). Praktikum z godivli silskohospodarskich tvarin: navchalnii posibnik. Praktikum $\mathrm{z}$ godivli silskohospodarskich tvarin: navchalnii posibnik. Kiev (in Ukrainian).
Busenko, O.T., Stolyk, B.D., Mogilnii, O.I. (2015). Technologia virobniztva produczii tvarinniztva: Pidruchnik. K.: Vischa osvita (in Ukrainian).

Kostenko, B.M., Panko, B.B., Sirovatko, K.M. (2008). Praktikum z godivli silskohospodarskich tvarin. Chimichnii sklad, ozinka pozhivnosti ta yakosti kormiv. Chastina I. Vinniza: RVB VDAO (in Ukrainian).

DSTU ISO 5983:2003. Kormi dla tvarin (2005). Viznachenna vmistu azotu i obchislenna vmistu sirogo bilka. Metod Kjeldahla (ISO 5983: 1997, IDT). Kiev, Derzhspozhyvstandard Ukraini (in Ukrainian).

GOST R 54390-2011. Producti pizhevii (2013). Opredelenija obzheho soderzanija azota putem sziganija po medodu Duma i raschet soderzhanija belka. Chast 2 . Zernovii, bobovie i molotie zernovie producti (ISO/TS 16634.2: 2004). Moskva, Standardinform (in Russian).

Bekker, Yu. (2009). Spectroskopija. M.: Technosphere (In Russian).

Sadchikova, N.P., Arzamastsev, A.P., Titova, A.V. (2008). Sovremennoe sostojanie problem primenenija IK-spectoskopii $\mathrm{v}$ pharmazevticheskom analize lekarstvennikh sredstv. Khimiko-Pharmacevtichnii zurnal. 8, 26-30 (In Russian).

Scheeren, T.W., Schober, L.P., Schwarte, L.A. (2012). Monitoring tissue oxygenation by near infrared spectroscopy (NIRS): background and current applications. Journal of Clinical Monitoring and Computing. 26(4), 279-287. 